\title{
Blue Ocean Strategy Analysis on SMEs Mochi Sukabumi
}

\author{
R. Deni Muhammad Danial ${ }^{1}$, Kokom Komariah $^{2}$, Nor Norisanti ${ }^{3}$ \\ \{rdmdanial043@ummi.ac.id ${ }^{1}$, ko2mpuspa@ummi.ac.id², nornorisanti@ummi.ac.id ${ }^{3}$ \} \\ Universitas Muhammadiyah Sukabumi, Indonesia ${ }^{1,2,3}$
}

\begin{abstract}
Mochi is a food product that characterizes the Sukabumi region. Because of typical food product, mochi is the main souvenir of food sought and bought by people outside Sukabumi who are on a tour in the Sukabumi area. Small and Medium Enterprise (SME) Lampion is the first SME in Sukabumi to produce mochi. The growing demand for mochi, especially from outside the Sukabumi region, has encouraged the growth of mochi SMEs besides Lampion. Now, there are three other mochi SMEs that are growing and developing besides Lampion, they are: Bakat Jaya, Putra Mandiri and Kharisma. The competition of the four mochi SMEs is getting higher and tighter over time. This study deals with strategic management and this research has objective, it is to determine which mochi SMEs are already using the Blue Ocean Strategy through the Canvas Strategy. The research method used is descriptive method with cross sectional approach. The result of this study is Lampion Mochi SME which has implemented the Blue Ocean Strategy. That is, Lampion dares to get out of existing competition by developing the uniqueness of SME in the presence of café and non-branch.
\end{abstract}

Keywords: Blue Ocean Strategy, Canvas Strategy, Strategic Management, and SMEs.

\section{Introduction}

Sukabumi (both district and city) is an area that offers a variety of beauty of natural and culinary tourism. In addition to offering natural attractions, Sukabumi also has several culinary tours, one of them is legendary special food and always hunted by newcomers, it calls as Mochi cake. Mochi is food which is processed and shaped to be a small ball, chewy texture, and sweetness. There are several variants of taste including durian, cheese, chocolate, strawberries, green beans, pineapple, and others.

The main raw material for making mochi is sticky rice flour, and the flour is cooked until glutinous. After that, the dough is formed into boxes and filled with crushed sweet peanuts, then formed roundly and sprinkled with starch to prevent sticking. These snacks are sold in the form of small baskets made of bamboo. Sukabumi people call it by the name of "besek". Cake that feels chewy in the mouth initially only has one flavor, it calls as the taste of pandanus which is often called the original taste.

The name of the mochi cake does indeed smelled Japanese because it is said to have originated from there. Some countries around Japan also know mochi, such as Taiwan, South Korea, and China. Why Sukabumi is known as souvenirs of Mochi cake? The story cannot be separated from the legendary SME Mochi named as Lampion that was founded in 1983. SME Lampion is now managed by Nanti Kustriana. Nanti is the granddaughter of a grandmother who 
lived during the Japanese occupation in Indonesia. Her grandmother would get a mochi recipe from a Japanese person he used to work with. The mochi recipe is then passed on to commercial products by her father. Her father changed the size of the traditional Japanese cake to smaller.

For more than 35 years, in Gang (alley) Kaswari there has only been a mochi lampion factory. Since 2006, Gang (alley) Kaswari began to emerge other craftsmen, one of them is Ujang Sukarya, the owner of Bakat Jaya mochi business. He founded the Bakat Jaya mochi business in 2006 and has 35 employees. In one week, he produces 5,000 mochi baskets (one basket of five baskets). The price of mochi per basket is Rp. 30,000 at that time. For long holydays, Ujang produces mochi twice of the production of ordinary days. Within a month, the turnover he achieved could reach Rp. 250 - 300 million. To increase his turnover, Ujang opened a branch on Jalan Pelabuhan Ratu. In Sukabumi, there are currently more than 11 mochi cake crafters. They are spread from large scale to home scale. They are scattered in several places namely Jalan Otista, Jalan Ahmad Yani and Jalan Surya. Beni, successor to the Mochi Berkah family business located on Ahmad Yani street, claimed to produce mochi cakes based on orders. Besides Lampion, Bakat Jaya and Berkah, there are many other mochi SMEs such as Putra Mandiri and Kharisma, the five SMEs are located in Gang Kaswari. Not to mention, there are more than 6 mochi SMEs scattered in various regions in Sukabumi. Although there are more than eleven SMEs mochi, in this paper, the author tries to compare only 4, they are: Lampion, Kharisma, Bakat Jaya and Putra Mandiri.

\section{Research Methods}

The research method used is descriptive method with cross-sectional approach. In social science research, a cross-sectional approach is a type of observational study that analyzes data from a population or from a representative section at a particular point in determined time. In other words, cross sectional method or often called as data one time is a collection of data to examine a phenomenon in a certain period of time [1]. This method was chosen because it studied objects in an unsustainable manner for a long period of time.

The analytical steps taken to determine how the SMEs Mochi have implemented the Blue Ocean Strategy can be seen in the following scheme: 


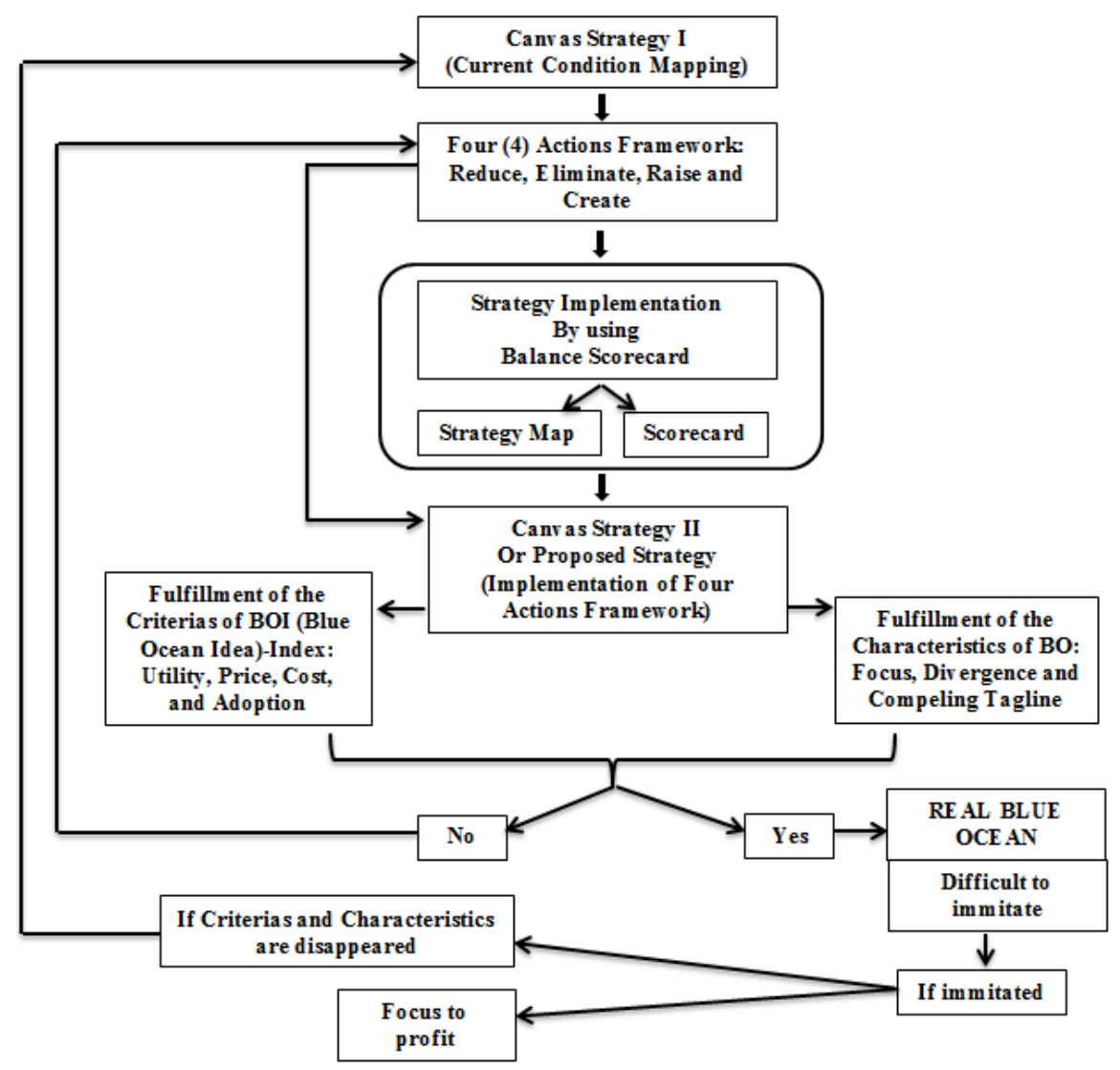

Fig. 1. Scheme of Analisys Step of Blue Ocean Strategy (Research Result, 2018).

In this study, the use of the balance scorecard was omitted because it was not the main element determining the implementation of the Blue Ocean Strategy. Likewise, the use of the Blue Ocean Idea (BOI) Index was also eliminated. BOI Index is only a complement to the implementation of the Blue Ocean Strategy, so that its existence can be replaced by the characteristics of the Blue Ocean Strategy in the form of focus, divergence and compeling tagline.

\section{Results and Discussion}

Blue Ocean Strategy is a marketing theory initiated by two professors of international strategy and management from INSEAD named W. Chan Kim and Renée Mauborgne. INSEAD (Institut Européen d'Administration des Affaires) is one of the largest business schools in the world domiciled in France. Blue Ocean is a strategy that challenges companies to get out of Red Ocean in which there is bloody competition in a way to create market space that does not yet have competitors, so the term "competition" becomes irrelevant [2]. Blue Ocean focuses on how 
to grow demand and always stay away from competition by creating a value and uniqueness that is not just unique, but also a very profitable market share.

Kim and Mauborgne stated that the Blue Ocean Strategy is an attempt to create differentiation and low prices together. The purpose is not to join competition in existing industries, but rather to create new market spaces, and making competition is irrelevant [3].

SMEs Mochi observed were Lampion, Bakat Jaya, Putra Mandiri and Kharisma. The names of the SMEs become the brand name for their products. Thus, the mention of the names of SMEs is also the mention of the product brand. To analyze the implementation of the Blue Ocean Strategy in the 4 SMEs, the following steps are carried out:

\subsection{Developing a Canvas Strategy for Mapping the Current Situation}

The first tool used to detect Blue Ocean Strategy implementation is the Canvas Strategy. Canvas Strategy is a framework used to diagnose and execute Blue Ocean Strategy. The purpose of using Canvas Strategy is to capture the position of a company that is in the market. When a company knows its position in the market, a company will understand what factors are competed in relation to the products which the company provides to customers, and whatever offering received by customers as a result of market competition [4].

To compile a Canvas Strategy, information about product quality for food and external factors that support product quality is needed. Product quality and external factors that support the quality of this product will be an element in determining product quality in an integrated manner. From these elements, Canvas Strategy will be mapped.

Regarding the product quality for food, according to [5][6], in outline, the dimensions of food quality are as follows: a. Color. The colors of food ingredients must be combined in such a way that they do not look pale or the colors do not match; b. Appearance. Food must be well seen while on a plate, this is an important factor. The freshness and cleanliness of the food served is an important example that will affect the appearance of the food whether good or not to be enjoyed; c. Portion. In each serving of food, the standard portion has been determined, it is called as the standard portion size; $d$. Shape. The shape of food plays an important role in eye attractiveness; e. Temperature. Consumers like variations in temperature obtained from one food to another. Temperature can also affect the taste, for example the sweet taste in a food will be more felt when the food is still warm; f. Texture. There are many food textures including smooth or not, liquid or solid, hard or soft, dry or moist. Thin and fine levels and shape of food can be felt through pressure and movement in the mouth; g. Aroma. Aroma is a reaction from food that will affect consumers before consumers enjoy food, consumers can smell the food; $h$. Level of cooking maturity. The level of food maturity will affect the texture of the food; i. Taste. The taste point of the tongue is the ability to detect the basis of sweet, sour, salty, bitter. In certain foods, these four flavors are combined to make one unique and interesting taste to be enjoyed.

In addition to product quality, other factors, namely external factors that shape product quality in an integrated manner, must also be taken into account such as packaging, price, and the place where the goods are sold. These factors determine the overall quality of the product. 


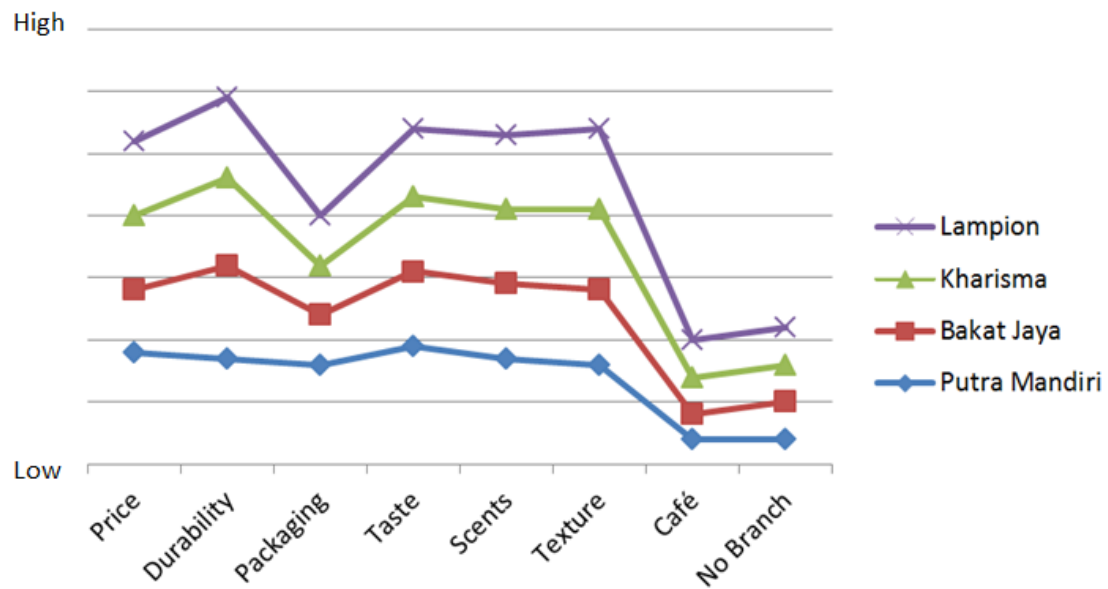

Fig. 2. Canvas Strategy for Mapping the Current Conditions (Research Result, 2018).

\subsection{Implementing the Four Actions Framework}

This framework is the next tool after the Canvas Strategy to diagnose and execute the Blue Ocean Strategy. The framework can be described as follows:

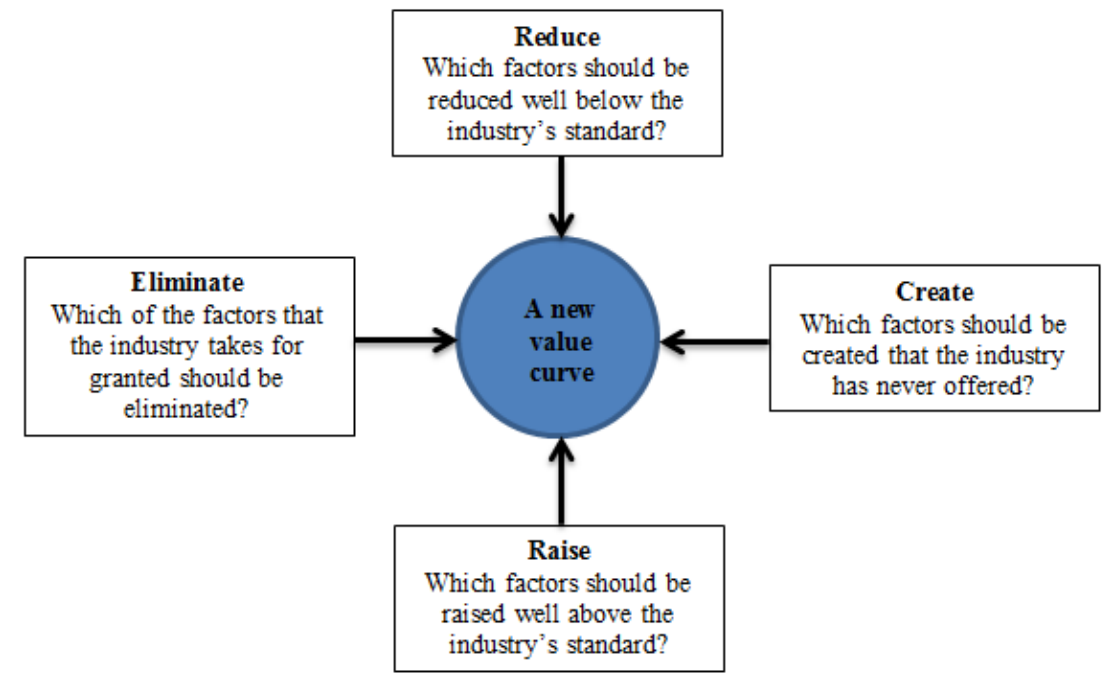

Fig. 3. Four Actions Framework [7].

This framework has four actions, the actions are: Reduce, Eliminate, Raise and Create. "Reduce" is related to what factors should be reduced from industry standards; "Eliminate" is related to what factors the company takes that is in the reality to be eliminated; "Raise" is related to what factors should be raised from industry standards; and "Create" is related to what factors must be created that have never been offered by the industry before [8].

This framework is used as the basis for developing the next Canvas Strategy. By doing the 4 things above, it will create a new curve after doing the new Canvas Strategy. With this last 
Canvas Strategy, a company is expected and considered to have implemented the Blue Ocean Strategy.

After the current conditions are mapped in the form of a Canvas Strategy, then start analyzing the four actions framework as follows:

\begin{tabular}{|l|l|}
\hline \multicolumn{1}{|c|}{ Eliminate } & \multicolumn{1}{c|}{ Raise } \\
\hline $\begin{array}{l}\text { What must be removed: } \\
\begin{array}{l}\text { a) There are no artificial preservatives. } \\
\text { b) Difficulty in carrying }\end{array}\end{array}$ & $\begin{array}{l}\text { What to improve: } \\
\text { a) Prices must be stable } \\
\text { b) Improved durability } \\
\text { c) Added flavor variants } \\
\text { d) More fragrant and natural aroma } \\
\text { e) Smoother texture } \\
\text { f) Tester }\end{array}$ \\
\hline $\begin{array}{l}\text { What to reduce: } \\
\text { a) The length of service time } \\
\text { b) The use of plastic }\end{array}$ & $\begin{array}{l}\text { What to do: } \\
\text { a) Café }\end{array}$ \\
\hline
\end{tabular}

Fig. 4. Analisys of Four Actions Framework (Research Result, 2018)

\subsection{Developing a Second Canvas Strategy for Creating a Blue Ocean Strategy}

After the analysis of the four actions framework is carried out, the next step is to compile the next Canvas Strategy based on the analysis of the previous four actions framework. The compiled Canvas Strategy can be seen in the following curve:

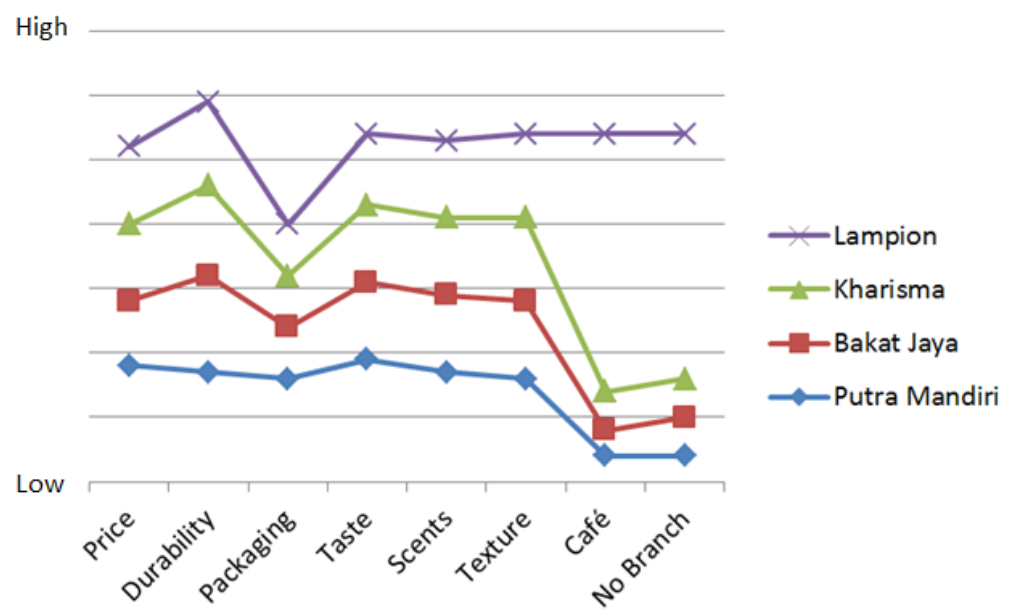

Fig. 5. Canvas Strategy for Proposed Strategy (Research Result, 2018)

\subsection{Analyzing the Characteristics of Blue Ocean}

After the framework is passed and a new strategy is made, it will appear that the company is using Blue Ocean Strategy or not. It will be called as using the Blue Ocean Strategy if it has 
the following characteristics [7]: 1) "Focus", it is the more focused the better, the strategy that is not focused will result the strategy that is not leading to one goal and instead it will be trapped in increasingly unclear situations; 2) "Divergence", the curve produced by the new Canvas Strategy must be completely different, not to be trapped in a similar pattern in the industry generally; 3) "Compelling Tagline", A good Blue Ocean Strategy must have an attractive tagline where the stronger tagline will further strengthen the produced product.

The Canvas Strategy proposed above needs to be analyzed first by observing the Blue Ocean Strategy Characteristics. If it meets the characteristics of the Blue Ocean Strategy, the SME Mochi Lampion strategy can be said to have implemented the Blue Ocean Strategy. And if it does not meet the characteristics, then the preparation of the Canvas Strategy must be done again. Below is an analysis of the characteristics of the Blue Ocean Strategy that has been fulfilled by SME Mochi Lampion:

a) Focus. SME Mochi Lampion only focuses on 2 things, they are: Convenience of the transaction with the existence of a café and the ease of getting original products by not opening branches.

b) Divergence. The curves generated from the new Canvas Strategy are completely different from the mochi industry in general. Thus, the Blue Ocean Strategy has really been implemented.

c) Compeling Tagline. The tagline of SME Mochi Lampion is "Mochi Kaswari Lampion, Typical Souvenirs of Sukabumi, Not Opening a Branch". The meaning is, the first mochi product and the last mochi product is in the Gang (Alley) Kaswari called Lampion and deserves to be a typical souvenir of Sukabumi, there was no mochi product but only in Kaswari and named Lampion. This tagline further strengthens mochi products produced by Blue Ocean Strategy at SME Mochi Lampion.

\section{Conclusion and Recommendation}

\subsection{Conclusions}

The conclusions that can be made for this research are:

a) SME Mochi Lampion has implemented the Blue Ocean Strategy through stages in the form of: First stage, preparation of the first Canvas Strategy in order to map current conditions; the second stage, implementing the four actions framework for developing the next Canvas Strategy; the third stage, preparing a new Canvas Strategy based on the results of the implementation of the four actions framework; the fourth stage, analyzing the characteristics of the Blue Ocean to ensure that the new Canvas Strategy is the implementation of the Blue Ocean Strategy.

b) SME Mochi Lampion has carried out the Blue Ocean Strategy as evidenced by the implementation of the four actions framework. The evidences are SME Mochi Lampion added another element that formed the quality of the product in the form of providing cafes for transaction convenience, and SME Mochi Lampion has commitment not to open company branches.

c) SME Mochi Lampion has actually implemented the Blue Ocean Strategy after being analyzed through the characteristics of Blue Ocean in the form of focus, divergence and compeling tagline. The characteristics of Blue Ocean in the form of focus, divergence 
and compelling tagline have been met by SME Mochi Lampion, so it can be said that SME Mochi Lampion has implemented the Blue Ocean Strategy.

\subsection{Recommendations}

As for related to suggestions, the suggestions that can be raised related to this research are:

a) Every SME Mochi Sukabumi must direct its efforts to the Blue Ocean Strategy. It's time for them to get out of the competition in the Red Ocean area. And achieve optimal benefits that run in the Blue Ocean area.

b) Every SME Mochi that has implemented the Blue Ocean Strategy always gets a challenge in the form of imitation by another SME Mochi in the future. Therefore, hold on existing conditions and focus on increasing profits. But if it has lost its Blue Ocean characteristics, SME Mochi must quickly do the Canvas Strategy again.

\section{References}

[1] H. Umar, Metode penelitian untuk skripsi dan tesis bisnis. PT RajaGrafindo Persada, 2008.

[2] F. Abdi, "Blue Ocean Strategy; Definitions and Frameworks," Adv. Soc. Humanit. Manag., vol. 2 No 3, no. 2, pp. 122-125, 2015.

[3] R. Tavallaee, "The Blue Ocean Strategy, as revolutionary in the field of strategic management," Police J. Hum. Dev., vol. 24, pp. 55-77, 2010.

[4] W. C. Kim, Blue Ocean Strategy. Harvard Business Review. Cambridge: Harvard Business School Publishin, 2004.

[5] B. B. West, L. Wood, and V. F. Harger, "Food service in institutions.," Food Serv. institutions., no. 4th ed., 1966.

[6] P. M. Gaman and K. B. Sherrington, The science of food. Routledge, 1996.

[7] W. C. Kim and R. Mauborgne, Blue Ocean Strategy, Expanded Edition: How to Create Uncontested Market Space and Make the Competition Irrelevant. Harvard Business Review Press, 2015.

[8] W. C. Kim and R. Mauborgne, Blue Ocean Strategy: How to Create Uncontested Market Space and Make the Competition Irrelevant. Harvard Business School Press, 2005. 